\title{
Invasion of North American beaver (Castor canadensis) in the province of Magallanes, Southern Chile: comparison between dating sites through interviews with the local community and dendrochronology
}

\author{
Giorgia Graells ${ }^{1 *}$, Derek Corcoran ${ }^{2}$ and Juan Carlos Aravena ${ }^{1}$
}

\begin{abstract}
Background: Twenty beavers Castor canadensis (Castoridae) were initially introduced in the Argentinean portion of Tierra del Fuego Island, from where they have occupied most of the Fuegian Archipelago and even reached the continent. This invasion is causing great damage to the subantarctic forest ecosystems, and it is not known how fast the species is spreading. While there is an estimation of this advance using interviews, it is not known how reliable these are and they cannot be made in remote areas.

On the mainland, where beavers were present, their date of arrival was estimated using interviews and dendrochronology, and the dates obtained by both methods were compared for each site.

Results: Differences were found among the groups of respondents, according to property size, in their ability to detect changes in the environment made by beavers.

The dates of arrival estimated through dendrochronology are 23 years prior to those determined through surveys, and they generate a potential route of arrival from the Fuegian Archipelago and migration in the mainland. This route is more parsimonious than the route of dispersal generated through interviews.

Conclusions: Since it was determined that there is no relationship between the dates estimated through surveys and dendrochronology, it is not possible to determine how much lag there is from the time when changes in the environment are produced by beavers and the time when people notice this change. Our results indicate that this lag may not be constant among different groups of people.
\end{abstract}

Keywords: Beaver; Dendrochronology; Dispersal; Cross dating; Surveys

\section{Background}

Biological invasions are a problem of great importance because they have been responsible for economic problems (Pimentel et al. 2000; Curtis and Jensen 2004) and losses of biological diversity (Sala et al. 2000; Vázquez 2002).

Castor canadensis (Castoridae) is an invasive species in southern South America, and it has been classified as

\footnotetext{
* Correspondence: gygraell@gmail.com

'Universidad de Magallanes, Avenida Bulnes 01855, Punta Arenas 621 0427, Chile

Full list of author information is available at the end of the article
}

a harmful species by the Chilean government (SERVICIO AGRICOLA Y GANADERO, Subdepartamento de vida silvestre DIPROREN 2011). The beavers are capable of completely modifying their habitat by building a lodge and a dam (Muller-Schwarze and Sun 2003), cutting down Nothofagus trees more than $20 \mathrm{~m}$ away from their pond (Anderson et al. 2009) to build dams that can measure up to $1.5 \mathrm{~m}$ tall and $100 \mathrm{~m}$ long (Baldini et al. 2008). While they do this, they generate changes to the riparian environment that are only reversible at rates much slower than its natural rate, because they change the plant community structure and succession patterns 
and prevent the natural regeneration of forests and aquatic ecosystems (Anderson et al. 2006; Martínez Pastur et al. 2006). In such conditions, only the seedlings of Nothofagus antarctica are capable to establish successfully, which could help the regeneration of the riparian forest, but only in the long term (Anderson et al. 2009).

Since 1946, when 20 beavers were released in a single event in the Argentine side of the Island of Tierra del Fuego (Pietrek and Fasola 2014), the population of beavers has expanded to the whole of the island, most of the Fuegian Archipelago and even to the South American continent (Skewes et al. 2006). On the Chilean side of Tierra del Fuego alone, the beaver population has been estimated at around 41,000 individuals (Skewes et al. 2006), with lower densities in steppe ecosystems and higher densities in Nothofagus pumilio (Nothofagaceae) forests (Skewes et al. 1999). This difference has been interpreted as a preference of the species for forested habitat environment over the steppe (Skewes et al. 2006).

Skewes et al. (2006) recounted the information of beaver sightings in Tierra del Fuego Island (both Chilean and Argentinean side) and Dawson Island. This study was complemented by Anderson et al. (2009) by incorporating information on sightings in Hoste and Navarino Islands and the mainland, thus providing a general idea of the possible dates of migration of this species. However, the information obtained from surveys and interviews has not been updated in recent years and/or validated by other methods and further quantitative studies to measure the progress of the invasion determining arrival of the specie or at least the settlement date and/or the first sign watching.

Dendrochronological analysis is based on the seasonality of tree growth, determined by the annual cycle of climatic limiting factors resulting in time series of tree-ring width and density with annual resolution (Stokes and Smiley 1968; Cook and Briffa 1990; Boninsegna et al. 2009). Considering that woody species used by beavers in the region of Magallanes have only one ring per growing season, the determination of the dates of use of timber by beavers will be possible by cross dating of samples of dead trees with the series of growth rings of living trees whose age is known, since its last year of growth corresponds to the date on which the sample was collected. The dendrochronological approach is used to determine when a tree was cut by beavers, both during dispersal or when it has found a permanent establishment.

We hypothesize that if people perceive the changes in the environment produced by the beaver's damage, then the dates of arrival determined through interviews will match the dates of arrival determined by dendrochronological dating.
The specific objectives of this study were:

1. To estimate the dates of beaver arrival using interviews and develop a map of the putative progress of this species in areas of the Magallanes province.

2. To establish the relationship between different interviewed groups and the degree of success/failure in detecting beaver presence in the Magallanes province.

3. To determine the arrival of beavers by dendrochronological methods in sites of the Magallanes province with signs of beaver presence and make a map of beaver migrations.

4. To compare the information provided by dendrochronology and interviews.

In this paper, we compare the dates of arrival of the American beaver invasion to different sites within the province of Magallanes, determined by sightings of the species or their sign (gnawed trees, dams, and/or lodges) detected by people inhabiting contiguous areas and cross dating of affected trees through dendrochronology on sites with signs of beaver found in this area through surveys (Graells and Corcoran 2011).

\section{Methods}

\section{Study area}

The study was conducted in the Magallanes province corresponding to continental geographical area of the region of Magallanes and Chilean Antarctica (Figure 1). The area is characterized by atmospheric circulation, oceanic influence, and landscape factors that define the five climatic types: arid with steppe and cold (BSk), arid with desert and cold (BWk), temperate without dry season and warm summer $(\mathrm{Cfb})$, temperate without dry season and cold summer $(\mathrm{Cfc})$, and tundra (ET) (Peel et al.

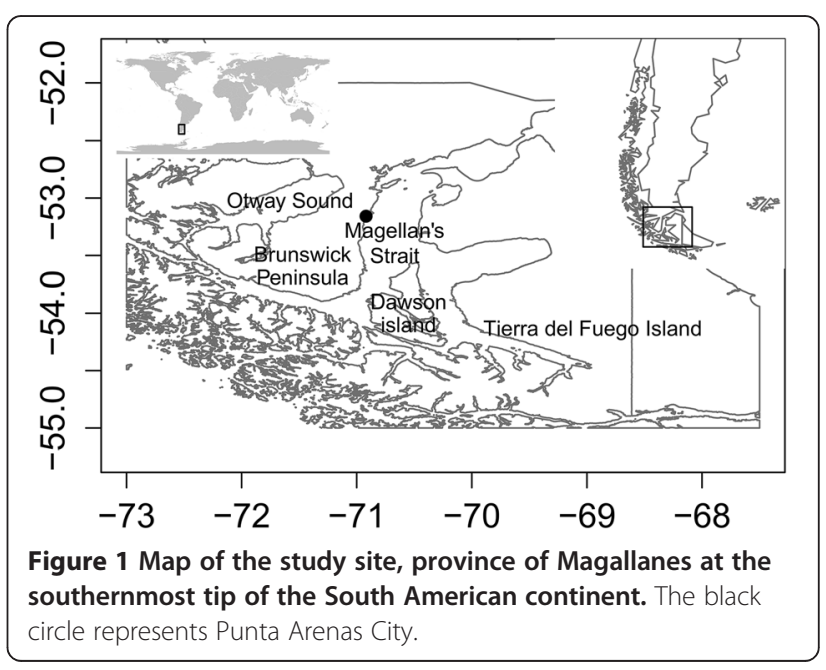


2007). The surveyed area considers the five climatic types. Sites dendrochronologically sampled were associated with cold-temperate environments $(\mathrm{Ckc})$. The vegetation in these environments is represented by mixed forest of N. pumilio and N. antarctica (Nothofagaceae) in the upper band, Magellanic deciduous forest of N. pumilio and Nothofagus betuloides (Nothofagaceae) evergreen forest at the bottom (Correa 1998).

\section{Interviews}

We estimated the perception of the date of arrival of beavers on the South American continent through interviews made in the Punta Arenas County, since this was the only county with a confirmed presence of beavers (Graells and Corcoran 2011). We used a questionnaire followed by a semi-directive interview (Huntington 2000), with the objective to survey most of the properties in the County. In order to do this, we went door to door in every house where someone was found and interviewed them. The questionnaire inquired about the presence or suspected presence of beavers or their signs, the date they saw the first beaver sign, considering presence of cut trees, dams, and/or beaver lodges. We established an area of perception in a range of $10 \mathrm{~km}$ of each surveyed property. The interviews were conducted face to face at the moment of the visit without announcement with landowners, tenants, and workers in agricultural and livestock farms, workers engaged in tourism, officials of armed forces and police, among others. The main activity of the individuals was recorded. We did not use maps during our interviews, because according to our experience, people working in sheep ranching in Magallanes, who possess low educational level, are intimidated by maps and get confused within their own geographical space when they look at them.

We used the oldest dates reported by the respondents as the estimated date of arrival for each river in the province and developed a map to visualize the possible route of arrival of beavers to the continent and their migration within it. For that purpose, we used the program DIVAGIS (Hijmans et al. 2004).

To estimate the relationship between the activity of the inhabitants and their success in detecting the presence or absence of beavers, we analysed 62 surveys. The surveyed people were categorized according to their main activity: owner of a small property ( $\leq 5$ hectares), worker of a small property, owner of a large property ( $>5$ hectares), worker of a large property, and visitor to a large property. We quantified the number of successes and errors at detecting the presence or absence of beaver sites by verifying suspicions by prospecting the river on foot (Graells and Corcoran 2011).

To establish if the ability to detect the presence of beavers is independent of the activity of the inhabitant or the size of the property, we performed a Fisher's exact independency test to see if there is a relationship between activities carried out by the respondents and the degree of correspondence of the responses to the presence of beavers and their actual presence. We also perform a chi-square test to determine differences in the correspondences of responses in large or small farms.

\section{Dendrochronology}

To estimate empirically the time of arrival of beavers into the Magallanes province, we sampled six of the eight sites prospected by Graells and Corcoran (2011), leaving out the Sanhueza Hotel (HS) as the only steppe site which did not have Nothofagus stumps and the sector of San Juan River (SJ), which was less than $10 \mathrm{~km}$ away from the San Pedro site and was far more difficult to sample because the beaver lodge was in the middle of a peat bog (Figure 2).

In each of the six sites, two cores were taken from each of 12 living trees $(n=144)$ using increment borers (HAGLOF, Sweden), and 7 to 12 cross sections of trees cut by beavers (depending on availability of the site and the conditions in which they were by the decomposition of wood) were collected. There were two types of sampling sites: In areas where beaver dams and/or lodges were found, samples were taken from living trees and stumps within a radius of $20 \mathrm{~m}$ from the lodge. When no beaver lodge or dam was found, we choose randomly a stump and sampled on an approximate 20 - $m$ radius from it.

Core samples were stored in plastic straws and cross sections in paper bags and properly identified per site; both were taken to the Dendrochronology Laboratory of CEQUA, a regional research center based on Punta Arenas.

The increment cores were mounted in wooden supports (Stokes and Smiley 1968; Phipps 1985) and fixed using a water-soluble glue, maintaining the correct alignment between the mount and the cells in the core. The core was hold in place with adhesive tape while the glue sets. Finally, increment cores and cross sections were prepared using a rotary-sanding tool through a range of grit size from 100 to 700 (Pilcher 1990).

After obtaining a clear exposition of the growth rings, their measurements were performed under a stereomicroscope using a $\times 15$ magnification. The width of each ring was measured and recorded digitally (VELMEX, New York, USA). The ring-width series obtained from living and dead trees were analysed using the program COFECHA (Holmes 1983). This computer program allowed us to detect errors in assigning ages of samples, generate a reference series or average for samples of living trees, and compare growth patterns of living trees (of known age) and dead (age unknown), allowing 


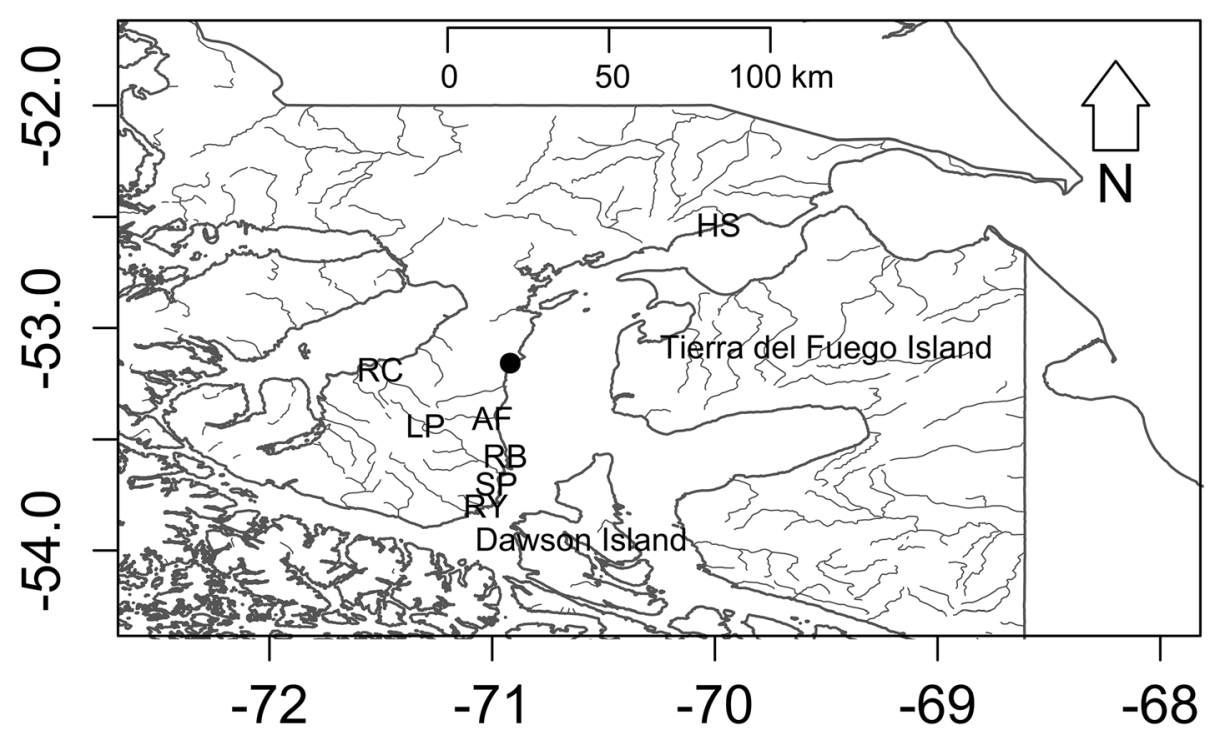

Figure 2 The seven sites of presence for beavers on the American continent confirmed by exploration of the area Graells and Corcoran (2011). RC, Caleta River; AF, Agua Fresca River; LP, Parrillar Lake; RB, Blanco River; SP, San Pedro River; RY, Yumbel River.

us to assign the date of death to the latter (Stokes and Smiley 1968).

The dates of the invaded sites obtained by dendrochronology were used to make a map with DIVAGIS. Using these dates, the likely route of arrival of the beavers to the mainland and their migration routes were inferred.

\section{Comparing surveys and dendrochronology}

To compare the oldest dated years obtained by both methods for each sample site, the years obtained by dendrochronology were considered as the independent variable and the dates obtained by surveys, as the dependent variable. The degree of dependency was tested by simple linear regression, considering an $\alpha$ of 0.05 .

\section{Results}

\section{Interviews}

A total of 62 surveys were conducted in the Magallanes province. Nine of the respondents reported at least a suspicion of beaver presence. Reported dates of the first sightings for suspected or confirmed presence of beavers were available for six sites (Table 1). These dates were considered as the tentative arrival dates of beavers at each site and were used to generate a hypothetical map of beaver dispersal from known points of presence on the islands of Tierra del Fuego and Dawson and movement across the continent (Figure 3 )

The map created from the dates obtained from the surveys suggests a possible migration route from Caleta River to the Strait of Magellan. The migration of Castor canadensis would have occurred from Caleta River crossing through Parrillar Lake and then dispersed by rivers that flow into the Strait of Magellan. The data do not rule out the possibility of beavers crossing from the islands of Tierra del Fuego and Dawson.

Of the 62 survey respondents, there were 25 owners of small properties, 5 workers of small properties, 15 owners of large properties, 14 workers of large properties, and 3 visitors to large properties. Statistical analysis indicated that the ability to assess beaver presence was dependent on the activity of the respondent $(P=0.00033)$. Owners of larger properties were more successful at properly assessing beaver presence than other groups, with 93\% of accuracy (Figure 4). On the other hand, owners of small parcels were the least successful group, with only $36 \%$ of the group properly evaluated the presence of beavers. Most differences were false negatives, i.e., the respondents were unaware of beaver presence within their premises or nearby areas.

Table 1 The sites for which respondents indicated the presence of beaver on the Brunswick Peninsula

\begin{tabular}{ll}
\hline Site & $\begin{array}{l}\text { Estimated time of arrival } \\
\text { through surveys (year) }\end{array}$ \\
\hline Los Patos Brook & 2011 \\
Blanco River area & 2010 \\
San Pedro Rriver area & 2008 \\
Yumbel Rivera area & 2008 \\
Parrillar Lake & 1994 \\
Caleta River & 1991 \\
\hline
\end{tabular}




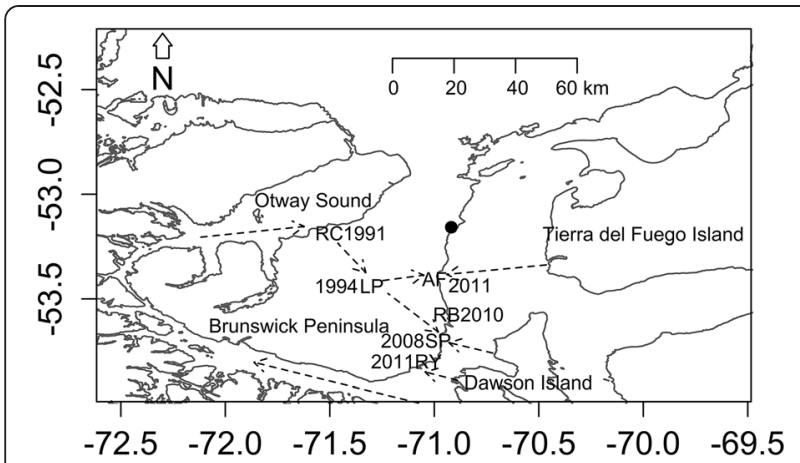

Figure 3 Map of Brunswick Peninsula and the dates of the first sightings of beaver in the various areas surveyed. The

hypothetical invasion route of Castor canadensis is traced from the Fuegian Archipelago. RC, Caleta River; AF, Agua Fresca River; LP, Parrillar Lake; RB, Blanco River; SJ, San Juan River; SP, San Pedro River; RY, Yumbel River.

\section{Dendrochronology}

Of the 144 cores collected, 135 were used to develop the reference series for each of the six sites. Nine cores were discarded because excess moisture and/or state of decay. Using those reference series, 107 trees cut by beavers were successfully cross dated. The average correlation with the reference series obtained for each site was 0.418 . At least eight trees were used on each site for the reference series determination ( 9.5 trees on average). On average, 17.83 trees cut by beavers were cross dated on each site, but only the samples that showed a correlation of 0.320 or higher were kept, resulting in a range of two to eight dated samples per site (Table 2).

For each site, the oldest date of the samples with a correlation index of 0.330 or higher was determined (Table 3). On the eastern shore of the Brunswick Peninsula (closest continental coastline to Tierra del Fuego), the San Pedro River had the oldest recorded beaver activity with trees being cut in 1968 (correlation with the reference series of 0.660 ). Then, proceeding from oldest to most recent sites, we have Blanco and Yumbel Rivers since 1976 $(r=0.485$ and 0.780 , respectively) and the Agua Fresca River from $2010(r=0.840)$. Inland of the Brunswick Peninsula, Parrillar Lake cut trees indicate beaver activity at least since $1996(r=0.330)$. On the western shore of Brunswick Peninsula (further away from Tierra del Fuego Island), we only have the Caleta River, where the oldest recorded activity was determined to be in 1986 $(r=0.380)$.

The oldest dates found for tree cutting from each site were considered as an estimation for the date of arrival to the area. Arrival dates were used to infer a map of beaver dispersal from nearby points with known presence of beaver on Tierra del Fuego and Dawson Islands and movement across the continent (Figure 5).

The inferred migration route (Figure 5) indicates that the first beavers to reach the Brunswick peninsula probably crossed to the area of San Pedro River from Dawson Island on 1968, the Yumbel and Blanco River could also be crossings from Dawson or Tierra del Fuego or from a secondary migration from the San Pedro River. The

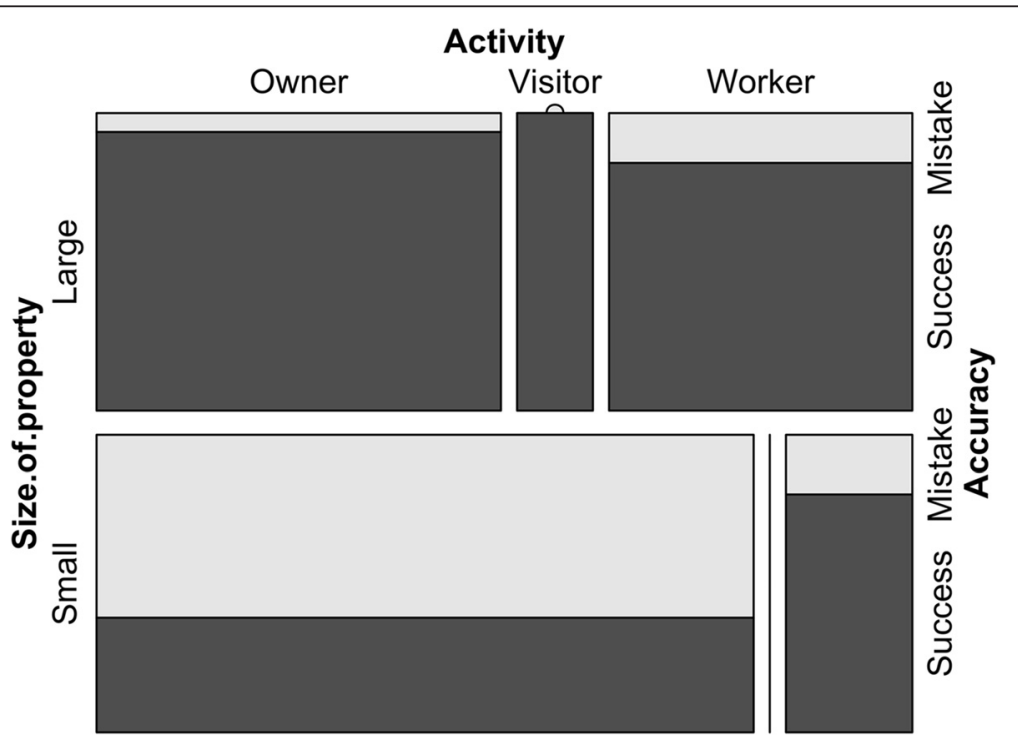

Figure 4 Mosaic plot showing the proportion of respondents which agree or differ with the presence or absence of beavers. We show the differences of the answer proportions (black agreement, grey differences) between size of property and people activities. The areas are proportional to the number of respondents. 
Table 2 Summary of the six sites where the dendrochronological sampling for living trees and beaver stumps was performed

\begin{tabular}{|c|c|c|c|c|c|}
\hline Site & $\begin{array}{l}\text { Number } \\
\text { of living } \\
\text { trees } \\
\text { samples }\end{array}$ & $\begin{array}{l}\text { Correlation } \\
\text { index with } \\
\text { the master } \\
\text { series }\end{array}$ & $\begin{array}{l}\text { Number } \\
\text { of living } \\
\text { trees } \\
\text { used for } \\
\text { cross } \\
\text { dating }\end{array}$ & $\begin{array}{l}\text { Number } \\
\text { of } \\
\text { samples } \\
\text { from } \\
\text { stumps }\end{array}$ & $\begin{array}{l}\text { Number of } \\
\text { samples } \\
\text { with a } \\
\text { correlation } \\
\text { index } \\
>0.330\end{array}$ \\
\hline $\begin{array}{l}\text { Caleta } \\
\text { River }\end{array}$ & 23 & 0.365 & 10 & 16 & 6 \\
\hline $\begin{array}{l}\text { Parrillar } \\
\text { Lake }\end{array}$ & 24 & 0.324 & 9 & 16 & 2 \\
\hline $\begin{array}{l}\text { Agua } \\
\text { Fresca } \\
\text { River }\end{array}$ & 22 & 0.405 & 10 & 20 & 2 \\
\hline $\begin{array}{l}\text { Blanco } \\
\text { River }\end{array}$ & 22 & 0.473 & 8 & 18 & 8 \\
\hline $\begin{array}{l}\text { San } \\
\text { Pedro } \\
\text { River }\end{array}$ & 24 & 0.397 & 10 & 16 & 7 \\
\hline $\begin{array}{l}\text { Yumbel } \\
\text { River }\end{array}$ & 20 & 0.408 & 10 & 21 & 8 \\
\hline Total & 135 & - & 57 & 107 & 33 \\
\hline Average & 22.5 & 0.418 & 9.5 & 17.8 & 5.5 \\
\hline
\end{tabular}

Sample numbers and correlation coefficients obtained by cross dating are indicated.

Caleta River was probably reached using a transpeninsular route going through Parrillar Lake since there is no presence of beaver in nearby islands. The migratory route suggests that the presence of beavers in the Agua Fresca River could be due to a migration from Parrillar Lake or a late crossing from Tierra del Fuego in 2010.

\section{Comparison of surveys and dendrochronology}

There were five sites where dating by both methods was possible Yumbel (RY), Blanco (RB), San Pedro (SP), and Caleta (RC) Rivers in addition to Parrillar Lake;

Table 3 Sites of beaver presence in Brunswick Peninsula and stimated date of arrival obtained by dendrochronology

\begin{tabular}{llll}
\hline Site & $\begin{array}{l}\text { Code of the } \\
\text { sample }\end{array}$ & $\begin{array}{l}\text { Correlation index } \\
\text { of the simple with } \\
\text { the master series }\end{array}$ & $\begin{array}{l}\text { Estimated time of } \\
\text { arrival through } \\
\text { cross dating }\end{array}$ \\
\hline Caleta River & RC1V1 & 0.380 & 1986 \\
Parrillar Lake & LP1V5 & 0.330 & 1996 \\
Agua Fresca River & AF1V4 & 0.840 & 2010 \\
Blanco River & RB1V1 & 0.485 & 1976 \\
San Pedro River & SP1V4 & 0.660 & 1968 \\
Yumbel River & RY1V6 & 0.780 & 1976 \\
\hline
\end{tabular}

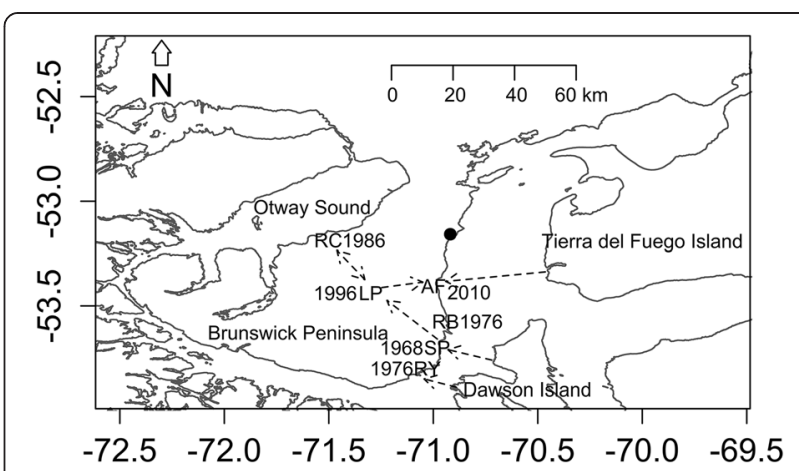

Figure 5 Brunswick Peninsula map and estimated date of arrival of beavers in the various areas surveyed. The

hypothetical invasion route of Castor canadensis is traced from the Fuegian Archipelago. RC, Caleta River; AF, Agua Fresca River; LP,

Parrillar Lake; RB, Blanco River; SJ, San Juan River; SP, San Pedro River; RY, Yumbel River.

consequently, it was possible to make a methodological comparison through a simple linear regression. Although the relationship between dates determined by the two methods showed a negative trend, it was not significant $(P=0.238)$.

\section{Discussion}

The invasion of Castor canadensis is a good model to monitor the development of a biological invasion. First, beavers leave a trail of dams and cut trees which are samples suitable for dendrochronological analysis (Muller-Schwarze and Sun 2003). Also, the Magellanic forest, either evergreen or deciduous, is almost monospecific with dominant species like $N$. pumilio and $N$. betuloides, which do not regenerate from stumps (Pisano 1977), thereby facilitating species identification, and an ideal system for cross dating in order to estimate the beaver migration paths. This system allowed us to date invaded sites that previously were dated only through surveys (Skewes et al. 2006; Anderson et al. 2009).

Although surveys provide valuable information on the perceptions of the community, the time required for people to notice changes in nature has not been considered, and this work shows that there is a significant but not constant delay. Estimated dates of first sighting and dendrochronology were mismatched. Even though both solutions are possible, the migration route established through the dates obtained by dendrochronology is shorter than that of obtained by interviews. According to the principle of parsimony (Baker 2003; Baker 2007; Mayo-Wilson 2009), the route determined by interviews could be considered it less likely than the one determined by dendrochronology. Moreover, the analysis of surveys indicates that the activity of a respondent is predictive of the congruence of dates between dendrochronology and 
the interviews (Figure 4). While the owners and employees of large and small properties alike usually inspect their property, owners of large properties go through more area, giving them a sampling advantage over owners and employees of small sites.

Dendrochronological analysis provides a systematic methodology that resulting in absolute dates of beaver arrival, where each sample of a tree cut by beavers is cross dated with a reference series of living trees, giving a correlation value. Although we worked using high correlation values ( 0.330 or higher), there are parameters that can limit the sampling methodology. For example, in two of the sites studied (Caleta River and San Pedro River), all the trees cut by beavers were sampled (while in Yumbel River and Parrillar Lake approximately 10\% of the trees were sampled, with $50 \%$ and $20 \%$ of the trees on the Blanco River and Agua Fresca River sites, respectively). When the arrival dates were estimated, we assumed to have sampled the oldest felled tree, but as the percentage of trees sampled decreases so does the probability of finding the oldest cut tree. We tried to minimize this possible flaw by selecting the oldest looking stumps and sampling cut trees located closer to the river. Despite these considerations, Parrillar Lake presented sampling issues, because we were only able to sample an estimated $10 \%$ of the trees, resulting in a $10 \%$ probability of finding the oldest tree. This problem resulted in the oldest date determined by dendrochronology (1996) being later to the date detected by surveys (1994), probably because the oldest cut tree was not among the selected samples.

Considering this source of bias, the sampling of sites with low numbers of felled trees, in which all trees cut by can be accomplished, generates a greater dating accuracy of the migration route. However, loss of information can also occur from moisture conditions that accelerate the process of rotting stumps (possibly the oldest trees cut on each site) or by increasing the probability of error measuring growth rings due to adverse weather conditions (six of the eight samples had this problem in Parrillar Lake). Despite the potential drawbacks of the method, which determines the specific dates for each sampled tree, the oldest date among them is selected as an estimation of the date of arrival of beavers on a site, independent of the presence, activity, or concerns of the human inhabitants. Also, the net effect of these biases will always result in underestimation of antiquity of the date of arrival at a given site, that is, we can only make one type of mistake: by estimating that beavers arrived to a site later than the real date of arrival. Using these specific dates, we were able to establish a map that presents a plausible migration path which is more parsimonious than the map developed using surveys. This migratory route, besides being the shortest, shows a relationship with the geography of the peninsula, where the progress of migration is related to the connection between the basins. Thus, the arrival of beavers between 1968 and 1976 and its progress towards Parrillar lagoon after the arrival in Caleta River and Parrillar and to Agua Fresca River is more likely than the dispersion from Rio Blanco directly to Rio Agua Fresca where there are no rivers that communicate them.

\section{Conclusions}

Given the differences between dates established via dendrochronology and interviews in the province of Magallanes, we can assume in general that the dates established for Tierra del Fuego using surveys (Skewes et al. 2006; Anderson et al. 2009) should also have a delay in their estimation of the time of arrival for beavers. Therefore, the only reliable dates for the invasion would be the date of introduction to Tierra del Fuego in 1946 and the dates of arrival to the province of Magallanes in 1968. This work succeeds in presenting the first reliable map of migration for this invasive species in the Brunswick peninsula, showing an error of 26 years in the arrival of this species to the continent, rejecting previous hypothesis about continental settlement beavers.

Dendrochronology is a potential tool that has several uses for policy makers, eradication, and conservation planners, because the number of trees killed by this specie for a specific year and area could serve as an indicator of the abundance of this species or another species causing tree mortality.

Considering beavers alone, this technique could be useful in monitoring populations in eradication programs for the specie which are being planned for Europe (Lorvelec and Pascal 2005; Genovesi et al. 2012; Parker et al. 2012) and South America (Choi 2008; Parkes et al. 2008; Menvielle et al. 2010), to monitor the advance and activity of the same invasive species in Asia (Saveljev and Safonov 1999) and to monitor the reintroduced populations of both Castor canadensis and Castor fiber (Macdonald et al. 1995; Halley 2011; Baldwin 2013; Gibson and Olden 2014). This could also help in studying the populations of pest species which attack woody species such as bark beetles (Hadley and Veblen 1993; Fettig et al. 2006; Schwilk et al. 2006) or other herbivores and/or pathogens producing tree mortality (Augspurger 1984; Schowalter et al. 1986; Christensen et al. 1995; Cannicci et al. 2008).

\section{Competing interests}

The authors declare that they have no competing interests.

\section{Authors' contributions}

GG conceived the study and the design, worked in the acquisition of data, analysis and interpretation of data, and did most of the drafting of the manuscript. DC participated in the study's design, coordination, data acquisition, and analysis and helped to draft the manuscript. JCA has been involved in drafting the manuscript and revising it critically for important intellectual content and has given final approval of the version to be published. All authors read and approved the final manuscript. 


\section{Acknowledgements}

We acknowledge Center for Quaternary Studies (CEQUA) by facilitating the dendrochronological measuring instruments, Carla Henriquez, and CONAF staff, particularly Alejandra Silva and rangers of Parrillar Lake, by sampling permissions. We thank SAG for funding part of this work through Public Bidding No. 1162-4-LE11, project "Survey and control of new outbreaks of Castor canadensis in the province of Magallanes", especially Nicolás Soto and José Luis Cabello, LucoMolina by the audio-visual production and fieldwork support, and all the family for their unconditional support. GG thanks CONICYT Msc scholarship 2012. This is a contribution to the research program PMI MAG1203 "Gaia-Antártica: conocimiento y cultura antártica" of the Universidad de Magallanes.

\section{Author details}

'Universidad de Magallanes, Avenida Bulnes 01855, Punta Arenas 621 0427, Chile. ${ }^{2}$ Pontificia Universidad Católica de Chile, Avda. Libertador Bernardo O'Higgins 340, Santiago 833 1010, Chile.

\section{Received: 10 October 2014 Accepted: 11 January 2015 Published online: 05 February 2015}

\section{References}

Anderson CB, Griffith CR, Rosemond AD, Rozzi R, Dollenz O (2006) The effects of invasive North American beavers on riparian plant communities in Cape Horn, Chile: do exotic beavers engineer differently in sub-Antarctic ecosystems? Biol Conserv 128:467-474

Anderson CB, Martinez-Pastur G, Lencinas MV (2009) Do introduced North American beavers Castor canadensis engineer differently in southern South America? An overview with implications for restoration. Mammal Rev 39:33-52

Augspurger CK (1984) Seedling survival of tropical tree species: interactions of dispersal distance, light-gaps, and pathogens. Ecology 65:1705-1712

Baker A (2003) Quantitative parsimony and explanatory power. Br J Philos Sci 54:245-259

Baker A (2007) Occam's razor in science: a case study from biogeography. Biol Philos 22:193-215

Baldini A, Oltremari J, Ramírez M (2008) Impacto del castor (Castor canadensis, Rodentia) en bosques de lenga (Nothofagus pumilio) de Tierra del Fuego, Chile. Bosque Valdivia 29:162-169

Baldwin J (2013) Problematizing beaver habitat identification models for reintroduction application in the Western United States. Yearb Assoc Pac Coast Geogr 75:104-120

Boninsegna JA, Argollo J, Aravena JC, Barichivich J, Christie D, Ferrero ME et al. (2009) Dendroclimatological reconstructions in South America: a review. Palaeogeogr Palaeoclimatol Palaeoecol 281:210-228

Cannicci S, Burrows D, Fratini S, Smith TJ III, Offenberg J, Dadouh-Guebas F. (2008) Faunal impact on vegetation structure and ecosystem function in mangrove forests: a review. Aquat Bot 89:186-200

Choi C (2008) Tierra del Fuego: the beavers must die. Nature 453:968-968

Christensen KM, Whitham TG, Keim P (1995) Herbivory and tree mortality across a pinyon pine hybrid zone. Oecologia 101:29-36

Cook ER, Briffa K (1990) Data Analysis. In: Cook ER, Kairiukstis LA (eds) Methods in dendrochronology: applications in the environmental sciences. Springer Science \& Business Media, Berlin, pp 40-50

Correa MN (1998) Flora patagónica, Primera. Colección científica del Instituto Nacional de Tecnología Agraria, Buenos Aires

Curtis PD, Jensen PG (2004) Habitat features affecting beaver occupancy along roadsides in New York state. J Wild Manag 68:278-287

Fettig CJ, McMillin JD, Anhold JA, Hamud SM, Borys RR, Dbney CP et al. (2006) The effects of mechanical fuel reduction treatments on the activity of bark beetles (Coleoptera: Scolytidae) infesting ponderosa pine. For Ecol Manag 230:55-68

Genovesi P, Carnevali L, Alonzi A, Scalera R (2012) Alien mammals in Europe: updated numbers and trends, and assessment of the effects on biodiversity. Integr Zool 7:247-253

Gibson PP, Olden JD (2014) Ecology, management, and conservation implications of North American beaver (Castor canadensis) in dryland streams. Aquat Conserv Mar Freshw Ecosyst 24:391-409

Graells G, Corcoran D (2011) Informe final proyecto prospección y control de nuevos focos de Castor canadensis en la Provincia de Magallanes. Servicio Agrícola y Ganadero, Punta Arenas
Hadley KS, Veblen $\Pi$ (1993) Stand response to western spruce budworm and Douglas-fir bark beetle outbreaks, Colorado Front Range. Can J For Res 23:479-491

Halley DJ (2011) Sourcing Eurasian beaver Castor fiber stock for reintroductions in Great Britain and Western Europe. Mammal Rev 41:40-53. doi:10.1111/ j.1365-2907.2010.00167.x

Hijmans RJ, Guarino L, Bussink C, Mathur P, Cruz M, Barrentes I et al. (2004) DIVA-GIS. Versión 4. Sistema de Información Geográfica para el análisis de datos de distribución de especies. Guía de usuario. Centro Internacional de la Papa, Lima, Perú. $83 \mathrm{p}$

Holmes RL (1983) Computer-assisted quality control in tree-ring dating and measurement. Tree-Ring Bull 43:69-78

Huntington HP (2000) Using traditional ecological knowledge in science: methods and applications. Ecol Appl 10:1270-1274

Lorvelec O, Pascal M (2005) French attempts to eradicate non-indigenous mammals and their consequences for native biota. Biol Invasions 7:135-140

Macdonald DW, Tattersall FH, Brown ED, Balharry D (1995) Reintroducing the European beaver to Britain: nostalgic meddling or restoring biodiversity? Mammal Rev 25:161-200, doi:10.1111/j.1365-2907.1995. tb00443.x

Martínez Pastur G, Lencinas MV, Escobar J, Quiroga P, Malmierca L, Lizarralde M. (2006) Understorey succession in Nothofagus forests in Tierra del Fuego (Argentina) affected by Castor canadensis. Appl Veg Sci 9:143-154

Mayo-Wilson C (2009) A game theoretic argument for Ockham's razor. Department of Philosophy, Carnegie Mellon University, Master's Thesis

Menvielle MF, Funes M, Malmierca L, Ramadori D, Saavedra B, Schiavini A et al. (2010) American beaver eradication in the southern tip of South America: main challenges of an ambitious project. Aliens Invasive Species Bull 29: 9-16.

Muller-Schwarze D, Sun L (2003) The beaver: natural history of a wetlands engineer, 1st edn. Comstock Publishing Associates, Ithaca, N.Y

Parker H, Nummi P, Hartman G, Rosell F (2012) Invasive North American beaver Castor canadensis in Eurasia: a review of potential consequences and a strategy for eradication. Wild Biol 18:354-365

Parkes JP, Paulson J, Donlan CJ, Campbell K (2008) Control of North American beavers in Tierra del Fuego: feasibility of eradication and alternative management options. In: Advanced conservation strategies. Available via DIALOG http://advancedconservation.org/library/parkes_etal_2008.pdf. Accessed 8 Jun 2014

Peel MC, Finlayson BL, McMahon TA (2007) Updated world map of the Köppen-Geiger climate classification. Hydrol Earth Syst Sci Discuss 4:439-473

Phipps RL (1985) Collecting, preparing, crossdating, and measuring tree increment cores. US Geological Surveys, Water Resources Investigations Report 85: 4148

Pietrek AG, Fasola L (2014) Origin and history of the beaver introduction in South America. Mastozool. Neotropical. (in press)

Pilcher JR (1990) Sample preparation, cross-dating and measurement. In: Cook ER, Kairiukstis LA (eds) Methods in dendrochronology: applications in the environmental sciences. Springer Science \& Business Media, Berlin, pp 40-50

Pimentel D, Lach L, Zuniga R, Morrison D (2000) Environmental and economic costs of nonindigenous species in the United States. Bioscience 50:53-65

Pisano E (1977) Fitogeografía de Fuego-Patagonia chilena. Instituto de la Patagonia, Punta Arenas

Sala OE, Chapin FS, Armesto JJ, Berlow E, Bloomfield J, Dirzo R et al. (2000) Global biodiversity scenarios for the year 2100. Science 287:1770-1774

Saveljev AP, Safonov VG (1999) The beaver in Russia and adjoining countries. In: Busher D (ed) Beaver protection, management, and utilization in Europe and North America. Plenum Publishers, New York, pp 17-24

Schowalter TD, Hargrove W, Crossley DA Jr (1986) Herbivory in forested ecosystems. Annu Rev Entomol 31:177-196

Schwilk DW, Knapp EE, Ferrenberg SM, Keeley JE, Caprio AC (2006) Tree mortality from fire and bark beetles following early and late season prescribed fires in a Sierra Nevada mixed-conifer forest. For Ecol Manag 232:36-45

SERVICIO AGRICOLA Y GANADERO, Subdepartamento de vida silvestre DIPROREN (2011) LEGISLACIÓN La Ley de Caza y su Reglamento, 12th edn. Unidad comunicación y prensa, SAG, SAG, Santiago

Skewes O, Gonzalez F, Olave R, Ávila A, Vargas V, Paulsen P et al. (2006) Abundance and distribution of American beaver, Castor canadensis (Kuhl 1820), in Tierra del Fuego and Navarino islands, Chile. Eur J Wildl Res 52:292-296 
Skewes O, González F, Rubilar M, Quezada R, Olave R, Vargas V et al. (1999) Investigación, aprovechamiento y control del castor en islas Tierra del Fuego y Navarino. Informe Final, Servicio Agrícola y ganadero, Punta Arenas.

Stokes MA, Smiley TL (1968) Tree-ring dating. University of Chicago Press, Chicago

Vázquez DP (2002) Multiple effects of introduced mammalian herbivores in a temperate forest. Biol Invasions 4:175-191

Submit your manuscript to a SpringerOpen ${ }^{\circ}$ journal and benefit from:

- Convenient online submission

- Rigorous peer review

- Immediate publication on acceptance

- Open access: articles freely available online

- High visibility within the field

- Retaining the copyright to your article

Submit your next manuscript at $\boldsymbol{\nabla}$ springeropen.com 